\title{
School of Anak Laut (Sea Children): Educational Philanthropy Movement in Bajo Community of Three-Coral World Center
}

\author{
Muhammad Alifuddin', Alhamuddin ${ }^{2}$, Nurjannah ${ }^{3}$ \\ 13 Institut Agama Islam Negeri (IAIN) Kendari, Indonesia \\ 2Universitas Islam Bandung, Indonesia \\ alhamuddinpalembang@gmail.com
}

\begin{abstract}
This article provided an anlytical description of the Muhammadiyah philanthropic movement to the Bajo community in Wakatobi. There were three important points hacked in this study, namely: (1). Why did Muhammadiyah choose the domain of education for its philatropical movement in the Bajo community? (2). what was the pattern of Muhammadiyah's educational philanthropic movement in the Bajo community? (3). what was the Bajo community's response to the Muhammadiyah-based pure Islamic education philanthropy movement? Data collection was done through in-depth interviews, observation and documentation. Analyzing data used hermeneutic phenomenology approach. The results showed that the choice of moving in the realm of education by the local Muhammadiyah community was due to the essence of the education movement as a fulcrum for determining the quality of human resources, on the other hand expensive quality education services made most Bajo children to choose to go to sea rather than go to school. The choice of educational philanthrophy by Muhammadiyah was also due to the psycho-social reality of local children who were suspected of "experiencing" an inferiority complex when they interacted with the mainland children's community. The philanthropic movement pattern implemented by the local Muhammadiyah community was based on the philanthropic social movement, namely to form awareness of the local community about the urgency of education for future life continuity by relying on a belief system or religious basis. The smart work of the Muhammadiyah community combined with the positive action approach made the pure Islamic idea could be transformed into the Bajo cultural space through education and teaching in a natural humanistic manner, without causing controversy.
\end{abstract}

ARTICLE INFO

Article history:

Received

August 20, 2020

Revised

April 26, 2021

Accepted

May 17, 2021
How to cite

Journal Homepage

Keywords: Educational Philanthrophy, Bajo Community, Educational Philanthrophy Movement

Alifudin, M., Alhamuddin, A., \& Nurjannah, N.. (2021). School of Anak Laut (Sea Children): Educational Philanthropy Movement in Bajo Community of Three-Coral World Center. Jurnal Iqra' : Kajian Ilmu Pendidikan, 6(1). 164-179. https://doi.org/10.25217/ji.v6i1.1057

http://journal.iaimnumetrolampung.ac.id/index.php/ji/

icle under the CC BY SA license

https://creativecommons.org/licenses/by-sa/4.0/

\section{INTRODUCTION}

Over the years my paradigm of Muhammadiyah has followed the path of the majority of analysts who call Muhammadiyah an urban Islamic movement (Subki, 2019). In addition to reading from a number of references on related matters, such a 
perspective at least in a long period of time collaborates with the empirical facts that I witnessed. The magnificent Muhammadiyah business charity building sneaks behind tall buildings in the city. This condition is also found in Southeast Sulawesi, the fact of Muhammadiyah is the phenomenon of Kendari City and Bau-Bau. The year 2017 was the beginning when I began to get nervous about this view, from the height of the air through the wing window of the Wings Air that flew me from Kendari to Wakatobi, from a height a school-like building appeared, but it was located above the sea. The building "sneaked" into a village that was well known as a Bajo settlement. It was dimly visible from the air, the building blended with a number of "slum" dwellings around it, which was the shelter for Bajo fishermen when they returned home to explore the archipelago sea for months. After visiting the location with a number of friends who were members of the Muhammadiyah board, I finally learned that the building was a school created by fellow Muhammadiyah activists in Wakatobi. This fact can shift the paradigm or even the "stigma" that tries to classify Muhammadiyah as a symptom of the city - meaning that residents and Muhammadiyah activities only comb the urban residents, far from the village, farmers and fishermen community. As a layman of Science, I dare not say it. However, the view that put Muhammadiyah as an urban community and tended to be rigid in understanding the culture of the other party was again sued by facts that clearly showed that in a number of areas where the majority of the population were non-Muslims, such as NTT and Papua, Muhammadiyah was present to provide education and social services. These sociological and anthropological facts, for the time being, prove that the Muhammadiyah movement in the field of education does not only penetrate geographically but also cultural and religious boundaries. The institutional presence of Muhammadiyah by establishing mosques, schools and health facilities in various parts of the archipelago such as in Papua, Maluku and NTT, can be used as proof that Muhammadiyah is not only busy interacting with the urban middle class but also uniting hearts with rural communities to those who are different in religious choice.

Thus, my image that was originally firmly identified with Muhammadiyah as an urban phenomenon seemed "necessary" to be reviewed, given that Muhammadiyah's vigorous movement across geographical, sociological and anthropological boundaries made this organization look more populist than has been thought so far. If Muhammadiyah now looks more populist with social movements, it is actually not a completely new thing, this lawsuit has at least been voiced by Kuntowijoya who mentioned; the historical reality that is often forgotten by followers (and "enemies" / Muhammadiyah) is that $\mathrm{KH}$ Ahmad Dahlan as the founder of Muhammadiyah was very tolerant of the religious practices of his day, so that he could be accepted by all groups (Kuntowidjoyo, 2000: xi).

The presence of Muhammadiyah in the coastal area of Wakatobi again confirms that the institution that was founded by Ahmad Dahlan, in his age of more than 100 years really cross the line, not only in cities and inland, but now reaching coastal areas. The green color of the sun flag seems to oppose the stigma that was built on it, now fluttering in the coastal sea breeze as seen on a coral island rich in marine life in Wakatobi, Southeast Sulawesi. The beautiful presence of Muhammdiyah in this region is not in the center of the city, but rather in the slum Bajo village with a very high level of dropouts. The presence of Muhammadiyah in the traditional area of Sea Man (translating the language of anthropologists to refer to Bajonese) is not easy. Considering the Bajo tradition which is still very thick with the paradigm of the past about the power of the sea guard, combined with a ritual full of colorful offerings is 
one thing that is "quite" opposed by the Muhammadiyah missionary movement. Therefore, the name Muhammadiyah may be something "haunted" for the Bajo community because it might be a threat to their traditions. However, in reality, Muhammadiyah with the stigma that is always pinned on it as an anti-tradition institution that smells of superstition, heresy and khurafat, can easily be traced into the heart of settlements and where the Bajo people live and rest. More than that, Muhammadiyah was even given the power to use land to strengthen its existence in the region. Is the power to use the land to build a school given to Muhammadiyah a sign of a high level of trust in this organization? Not easy to answer. More interesting questions to be analyzed and answered analytically is; why did the Muhammadiyah community in Wakatobi prefer to establish schools at sea for Bajo children rather than establishing mosques or mushallahs?

A number of studies related to the use of philanthropic funds in education was conducted by Aan Nasrullah (2015), Joko Subando (2016), Rizka Amalia Shofa and Imam Machali (2017), Syauqi Futaqi and Imam Machali (2018). In general, the research above focus on the management of philanthropic funds for education financing by Islamic financial institutions, while this research focused on the philanthropic activities of Muhammadiyah residents to empower the coastal community of Wakatobi through educational services.

In addition to a number of studies above, there are still many results of research on philanthropy in the education world, such as Hilaman Latief's research: Filantropi dan Pendidikan di Indonesia. Latif's study is directed at answering the possibility that Islamic philanthropy can contribute to the development of Islamic education in Indonesia (Latief, 2016: 1). Studies that specifically focus on the theme of educational philanthropy are linked to the vigor of Muhammadiyah residents, due to author's knowledge and searches, have not been carried out intensively. One study that has close links with this research emerged with the theme: Perilaku dan Potensi Filantropi Warga Muhammadiyah (Survey di 11 Kota Besar Indonesia) (Latief, 2016). This study concludes that the perception of charity and generosity among Muhammadiyah residents shows that religious views are still very dominant. The study also explains the potential of Muhammadiyah philanthropic funds. Based on the capacity possessed by Muhammadiyah's business charity and the ability to issue existing social funds, there is at least potential of more than 365 billion rupiah of philanthropic funds that can be extracted and utilized annually (Latief, 2016). However, Latif's writing examines Muhammadiyah's philanthropy, the study is general and it focuses more on the mapping of the philanthropic potential of Muhammadiyah. In contrast to this study, that focuses on the Muhammadiyah empowerment movement at the grassroots.

Conceptually, philanthropy can be divided into two forms, namely traditional philanthropy and philanthropy for social justice. Traditional philanthropy is a charity based activity. Traditional philanthropic practices take the form of gifts for the benefit of social services, for example the direct giving of philanthropists to the poor in order to meet their daily needs. Because this type of philanthropy is not sustainable, this form cannot develop the standard of living of the poor, so it tends to have negative implications because people are taught to be "spoiled" and stand by.

In contrast to philanthropy for social justice (social justice philanthropy), which stands above the philosophical foundation to answer public problems with the hallmark of a program that is sustainable, moving in the macro realm, solving problems at the structural level and changing systems. This model is expected to bridge the gap between the rich and the poor, with efforts to mobilize resources to 
support activities that challenge structural injustice as a cause of lasting poverty. In other words, this type of philanthropy always seeks to find the root causes of poverty experienced by the community. The examples of this case are factors of injustice in the allocation of resources, funds, or access to power in society (Bappenas, 2010).

The ideas of Helmut K. Anheier and Diana Laet (2006) about "creative philanthropy" should be considered as an analytical tool to see the philanthropic model developed by a community. First, charity approach, this approach tends to highlight the symptoms of social problems rather than the background of the problem. Second, scientific philanthropy, this approach aims to resolve the causes of social problems. However, this approach often fails because it is focused on educational analysis and research alone, so the ability to see how long, how much it costs, how complex is often ignored, meaning that in terms of practical it is often overlooked. Third, new scientific philanthropy. This approach emphasizes process rather than role, and sometimes ignores the unique values of existing philanthropic institutions and distinguishes them from other institutions (Latif, 2010). Muhammadiyah's educational philanthropy in the Bajo community of Wakatobi as examined in this study in its implementation, by field actors, will not escape Islamic values. This becomes very reasonable because the basis and foundation of the movement of Muhammadiyah as stated in its articles of association is Islam.

This anxiety that drove the author to go deeper into analyzing the analytical criticism of Muhammadiyah's philanthropic choice by establishing a school for marine children in Bajo Mola Wakatobi. In addition to the aforementioned aspects, this study also sought to uncover the surface about the philanthropic movement patterns and how the Bajo people responded to the Muhammadiyah philanthropic movement wrapped in pure Islamic paradigms?

\section{METHOD}

Muhammadiyah's Educational Philanthropy Movement at the World Coral Triangle Center reflects the interpretation of the Muhammadiyah community about the relationship between the educational philanthropy movement and the environmental conditions they face in a context of social structure that changes dynamically. This presuppose needs to put the theory in a critical position, in which the truth of both is not only seen from the ability to explain, but also in interpreting social and cultural realities, that are dynamic and free of ideological interests. Therefore, the research model was chosen which referred to qualitative data based on the perspective of the dialectical relations of religion and the social dynamics of its adherents. The data in this study were obtained through a series of in-depth interviews, participatory observation and study of documents. In an effort to capture the rhythm and way of thinking or work patterns of cultural systems, then in this context, researchers were stimulated to study a lot of details and they placed themselves in the sense of being there both intellectually and emotionally. This method was called by Geertz as thick description (anthropology interpretative), through this method, broad conclusions would be drawn from small things but composed of solid things. Thick description requires researchers to understand the particular culture and requires them to be directly involved with local cultural actors (Sutrisno \& Putranto, 2005: 212). Therefore, data analysis was carried out continuously, as long as the process was coded for what was found based on the context and perspective of the participants (Gay, 2000: 29). The procedure adopted was referring to the analysis of kanism developed by Miles, M. B., 
Huberman, A. M., \& Saldaña, J. (2018) combined with the phenomenological method of von Eckartsberg (Moustakas, 1994: 15-16).

\section{RESULT AND DISCUSSION}

\section{a. Glimpse of Bajo Mola}

Bajo people or in the term of Western researchers called Sea Man, is a community that lives in coastal areas and they make the sea as their "land". In Wakatobi Regency, there are a number of Bajo settlements, including in South WangiWangi known as Bajo Mola and in Kaledupa District known as Bajo Mantigola. It is not known exactly when they inhabited / settled in the region.

Although not a native of Wakatobi, for the local community, Bajo people have been seen as an inseparable part of the body from the Wakatobi people. This feeling may be because the Bajo people have inhabited the coast of the islands for decades with the livelihood of fishing, namely fishing, sea cucumbers, fish and seaweed farming.

For Bajo people, the sea is the epicenter of their lives. The sea is an inseparable part of their lives, so the sea seems to be the legacy of their ancestors. In reality, more than half of Bajo people's life activities are at sea. At sea, they settle and play the wheel of their lives or in other words, the sea is the place where the Bajo people depend on and earn a living. However, in an effort to search for life at sea, it is not uncommon for them to carry out "acts" of violence against marine biota, such as bombing, sedation and mining of coral and sea sand, in which when viewed from an ecological point of view, these actions are very detrimental because they have implications on nature destruction. Weakness or lack of education is one of the fundamental reasons for their ignorance of exploring the marine environment in a friendly manner. In addition, the demands of life and the economy "force" them to exploit aquatic resources beyond reason.

Although their existence has been recognized as an integral part of the Waktobi community, in reality the Bajo people experience what in psychology is called the inferiority complex. And because of that, until now the Bajo people live in groups of fellow Bajo people, so it is very rare not to say there are no Bajo people living together with local "residents". In the process of social interaction, Bajo people generally "position" themselves as second class society. This was revealed by Madlan, et al. who found that the understanding of other ethnic groups towards the Bajo was on the lower side (Madlan, 2014). The condition of inferiority complex seems to decrease in their children. Suryanegara explains that Bajo people tend to be rated "negative", so that they are sometimes harassed (Suryanegara, 2015). The condition as mentioned above is a reflection of the Bajo culture called olai lesse'e, which is trying to avoid bagai people (not people). Is the communication, in the era that is increasingly open like nowadays, still a common symptom in Bajo people? It seems that even the situation does not change 360 degrees, there is certainly a shift. This is as expressed by Nasruddin Sayuti, that to meet their various needs, Bajo people must establish cooperation with bagai people, therefore, the principle of the culture of olai lesse'e trying to avoid bagai people starts to change. The change is caused by a long-standing social interaction between Bajo people and outsiders. At that time, each culture is communicated and they try to make an interpretation of what they receive (Nasruddin, 2004).

The culture of olai lesse'e may not be handed down formally through family education, but the choice of a place to live in groups and tend to "alienate" 
themselves from land people, combined with the possibility that there is still a paradigm that lives among land-based people who see one eye on the existence of Bajo people, makes the olai lesse'e culture alive and influence their way of thinking. This condition may have implications for the choices of Bajo children to prioritize going down to the sea rather than continuing their education at school.

La Rudi, one of the teachers who interacted with Bajo children for a long time, stated that generally Bajo children were in groups of fellow Bajo people, they were less integrated because they seemed inferior. At the beginning of school, they joined in the study, but during the fishing season, they went out to sea to leave the school and came after the end of the exam. They tended to be difficult to manage. They were generally very difficult to mingle with the mainland people, they were in the same group as Bajo.

\section{b. Muhammadiyah School in Bajo: Empowerment of the Sea Children Community}

Wakatobi Regency is the division part of Buton Regency in 2004. The existence of Wakatobi which was previously only a number of districts became a separate Regency, also contributes to changes in the position of a number of social community organizations including Muhammadiyah. Previously, Muhammadiyah in this region was only a part or branch of Muhammadiyah based in Buton, with this change necessitating that the local Muhammadiyah community metamorphoses into a separate regional administration under the Regional Management of the Southeast Sulawesi Muhammadiyah Region. Muhammadiyah Regional of Wakatobi Regency was formed in 2007 whose coordination was driven from the Wakatobi Capital City, located on the island of Wangi-Wangi. Before Wakatobi became a separate district, it was known that Muhammadiyah's movements had been heard in this region, even though it was faint. But after Wakatobi stood alone as a district, then the active movement of Muhammadiyah began to appear. The activity was moved by a number of civil servant exponents from Muhammadiyah circles who chose the transfer to Wakatobi. They were La Tara Patra and Subair, two Muhammadiyah exponents who were considered "aggressive" in pushing Muhammadiyah's steps in this area. In their hands plus a number of Muhammadiyah cadres from Kendari and Maluku, the Muhammadiyah wheel was moved. Therefore, it does not take a long time a number of Muhammadiyah Charitable Enterprises, such as schools and even Muhammadiyah Universities were initiated by Muhammadiyah exponents. Although the intention to establish the University has not yet been realized, they have succeeded in establishing two high schools, namely Muhammadiyah I Wakatobi High School located in South Wangi-Wangi District and Muhammadiyah II Wakatobi High School, located in Kaledupa District, which is a separate island from the main district of Wakatobi. The beauty of the two educational institutions was built on the sea or in the middle of the Bajo settlement. This reality raises a question mark, why the choice of where to establish educational institutions are both located in the sea area?

$i$. The Background of Mahammadiyah School of Sea Children Establishment

In the empirical experience of La Rudi (a teacher) who has long interacted with Bajo children, stated that: generally students who come from the Bajo environment are "exclusive", they are generally very difficult to adjust to students who come from terrestrial communities. There is an impression that they are "difficult" to regulate, and even tend to pay less attention to existing regulations. In general, they send their children to school during the new school year, but these children generally disappear before the semester, and return to attend school after the semester age. Another 
apparent reality is that the Bajo children community tends to be underestimated by land people, making some of these communities tend to shut down and even become inferior. Under these conditions, the choice of going to sea and leaving school by some Bajo children becomes more meaningful to their lives than being and interacting with land children in school (Madlan, 2014). For some Bajo children, the school environment is sometimes not too friendly for them to develop themselves, so some of them prefer to return to the sea rather than linger on land. The choice of going to sea is caused not only by the things mentioned above, but also part of an existential calling of conscience. Bajo is going to sea and wandering, that is the paradigm that is still firmly embedded in the Bajo mindset. This is as mentioned by Ahimsa (Putra, 1995: 62) "to be an Bajo people they are wandering and visiting fellow Bajo people because through this activity, the Bajo people find their nature while maintaining the Bajo culture itself". This myth seems to answer La Rudi's confusion over the habits of a number of Bajo students who are impressed without regret leaving the learning process halfway through.

This reality appears explicit in the eyes of a number of Muhammadiyah Wakatobi exponents. Surni, a Muhammadiyah cadre from the local Bajo explained to the author that to educate Bajo children to be able to go to school as other children was to bring the school closer to the environment where they were raised, namely around the marine environment. That was why they chose to establish a school on the sea. Besides being close to the Bajo environment, this school also mostly accommodates Bajo children, making it possible for them to interact, develop and communicate their ideas more freely without feeling awkward. Referring to Surni's explanation as described, it shows a fact that Muhammadiyah's involvement in the Bajo environment by establishing a school for local children is due to psycho-social factors experienced by local children.

In addition to psycho-social factors, another reason for the establishment of schools in the middle of the Bajo environment by Muhammadiyah also departs from the reality of schooling today which tends to have been capitalized. This condition causes not all Indonesian children can easily continue their education, except for certain groups who have economic ability. Quality schools are no longer possible to be glimpsed by children who come from weak economic circles, as in general the Bajo people. In this context, Muhammadiyah felt the complaints from the weak economic community groups, especially those living in Bajo that triggered their adrenaline to try to provide space and learning opportunities without having to think hard about financing, by establishing Muhammadiyah School infrastructure for Bajo children in Mola Wakatobi. The third reason, the establishment of Muhammadiyah educational institutions for marine children is to bring community groups related to religion closer. The social problems faced by the Bajo community so far cannot be separated from the weakness of the religious spirit. Therefore, the school for marine children in Bajo not only serves to improve the intellectual aspects of their quition, but also plays role as a way to improve emotional and spiritual quition through religious literacy.

In addition to the three reasons mentioned above, other things that also triggered so that the school for children founded by the Muhammadiyah community cannot be separated from the "doctrine" of the organization attached to the Muhammadiyah exponent. Subair, for example, said that the establishment of Muhammadiyah educational institutions is a social calling and preaching that is driven by the organization in which it operates. He further stated that the doctrine of 
inevitability for Muhammadiyah cadres wherever they exist to establish an educational institution was the "will" of his teacher who was a Muhammadiyah figure when he studied in Malang 1972. The reason for Subair was in line with a number of Muhammadiyah exponents who were behind the establishment of Sea Children School, which was to move the da'wah within the framework of a progressing Islam with the aim of enlightening the minds of the children of the Sea at the Center of the World Coral Triangle.

\section{1) Governance of Mola Muhammadiyah Senior High School}

Muhammadiyah's activities to educate the nation's life as contained in the opening of the 1945 Constitution did not recognize land or sea. This effort was also carried out by the coastal Muhammadiyah community who are active in Wakatobi. 2012 was the start of the founding of the Muhammadiyah Mola High School which aimed to provide space and opportunities for Bajo children to receive education amid high school fees. Starting its educational movement, the Muhammadiyah community utilized (borrowed) Ediarto's house to serve as a study room. The house building was transformed by plotting the inside to become a study room. This house was made into a school for three years or once completed. Three years after the school carried out the teaching and learning process, the Muhammadiyah exponent together with KKA students of the Muhammadiyah University of Buton initiated a seminar with the theme: Urgensi Pendidikan bagi Anak-Anak Bajo, a seminar was held in the open by inviting the Regent of Hugua and the Head of the Education Department in Wakatobi. From the seminar, it was found that the highest dropout rate in Wakatobi was found in school-age children who lived in the Bajo Mola neighborhood. Because of this reality, all parties undoubtedly encouraged the awareness of Bajo people to send their children to school, including facilitating the implementation of educational institutions to be close to where Bajo children lived as a follow-up to the seminar, there was a deal between Muhammadiyah exponents and the local community to request the sea area to Mandati stakeholder in establishing Muhammadiyah High School. The Muhammadiyah's efforts were welcomed, so that a permanent school building was built, the construction of which was carried out by the Muhammadiyah community, the local community and supported by the Wakatobi Regional Government. On a further journey, the Mandati party authorized the use of the land in the form of a grant to the local Muhammadiyah. The sea area grant entrusted to Muhammadiyah has now reached 1 (one) hectare. Of this area, only one fifth of the total land area has been used.

In carrying out learning activities, the school that currently educates 102 students is led by 14 (fourteen) teachers. From this number, 3 (three) teachers are seconded teachers while the rest are volunteers who spend their time, energy and knowledge on Bajo children. Ali, the Principal who leads this school, is assisted by 11 (eleven) noncivil servant teachers who work with full dedication. To his teachers, Ali assured that if you do not get material rewards in this place, rest assured God will give it in a better form elsewhere. According to Ali's explanation, the management of Muhammadiyah High School so far has generally been voluntary based, because in reality, besides the cost of scholarships for poor children given by the state to students, there is no other funding. Therefore, for school operations, the school takes the initiative to raise funds through the ice cube sale business. The choice of business is quite strategic considering the Bajo area is a residence for fishermen, who at all times need ice cubes to preserve their catch. As initial capital, Ali the Principal was forced to lift his frezer to the School to be used as a business machine in order to finance school operations. In addition to these efforts, the school also made floating nets under the class, which were used to 
raise fish, but the ice cubes business seemed to be able to facilitate them to pay for school needs.

When asked whether the management of Muhammadiyah Senir High School was also assisted by BAZDA funds, Ali said that he had never even obtained funds from institution, even LAZISMU under Muhammadiyah management until now has not been interested in participating, so that the active movement of this school was actually carried out voluntarily by several Muhammadiyah communities that were concerned. What about reginal government involvement? Surni said: it was Hugua, the Regent of Wakatobi, during his leadership left little concern. According to Surni, there was Hugua's regret, why when at the end of his term of office he only knew that in the middle of the Bajo community who were economically and educationally disadvantaged in the Bajo community, there were people who gave their time, funds and energy to provide education services. There is an effort by the school to recollaborate with the government by proposing the construction of library in 2019, but political zigzag by a number of political party exponents had made efforts to pioneer a library building which was originally visited by the Cultural Education Office of the Southeast Sulawesi Province to stop in the middle of the road (Alhamuddin, Fanani, Murniati, \& Yasin, 2020). However, the determination and enthusiasm of the Muhammadiyah children to continue the institution was supported by a number of Muhammadiyah Student Ties alumni, who generally came from Buton Muhammadiyah University not fade. According to him, we are not moving because we hope for the assistance of the local government, if the collaborative efforts are carried out because we realize that the responsibility of education for Bajo children should not only be borne by the Muhammadiyah Wakatobi community which in reality is still very frail in human resources and funds, but requires the presence of the State in this matter represented by the Regional Government.

\section{2) Pure Islamic Spirit in the middle of Popular Islam Community}

Muhammadiyah's education has four functions, namely: first as a means of education and intelligence, secondly, community service, thirdly preaching amar ma'ruf nahi munkar and fourth, cadre regeneration. As a means of regeneration, Muhammadiyah hopes, through the educational institutions it builds, it can produce superior Muhammadiyah seeds which in the future can continue the mission of preaching Muhammadiyah in the community. In that context, the fundamental things that cannot be lost in Muhammadiyah educational institutions at all levels are the subjects on Al-Islam and Muhammadiyah terms. These subjects are projected to shape the knowledge and Islamic attitudes of students with Muhammadiyah character. Through these subjects, the pattern of child religiosity is formed based on Muhammadiyah's vision and mission, namely advanced and enlightening religions based on the conceptions built by Muhammadiyah.

The orientation as mentioned above was also instilled by Muhammadiyah teachers in students who were educated in the sea children school. Syarif, a volunteer teacher who teaches Al-Islam and Muhammadiyah terms, told the author; religious education becomes very important for children in Bajo, given their understanding of religion is so minimal that many things that are actually a past tradition are seen by them as religion itself. Our task is to correct this, if the tradition does not conflict with Islamic aqida then it does not matter, but if there are things that have the potential to violate the principles of Islamic teachings that lead to superstition, bid'ah and khurafat, we will correct them in wise ways. Therefore, in these lessons we always emphasize the students here. For references 
used in addition to using religious knowledge books published by central leadership of Muhammadiyah, in aqidah learning we also use aqidah book references written by Sheikh Ali Fawzan.

The character of Al-Islam and Muhammadiyah terms besides being transmitted through formal lessons in schools, it is also instilled through cadre organized by the Muhammadiyah Student Association. Syarif further said that there was a number of progress that could be felt with the presence of Muhammadiyah schools in this region. Bajo children who study at Muhammadiyah in addition to studying general subjects, some of them are also given additional lessons to memorize the Qur'an. Among our students who graduated and while studying there were those who had memorized up to 6 juz. According to Syarif, this is an extraordinary progress because such achievements have never been imagined for children in this region.

Moving on from the description above, it appears explicit that there was a strong effort from the educator component in the school of marine children, especially from the young Muhammadiyah group to transform the pure Islamic paradigm in the learning of aqidah. This is indicated by the explanation of Syarifuddin who uses the reference to the Tawheed Book of Sheikh Ali Fawzan. According to him, tawhid learning is emphasized given that there are still many students involved in superstitious traditions. Through intense learning and discussion, Syarif continued: many children were enlightened in their understanding. Besides Syarif teaching in Muhammadiyah High School, he also teaches and at the same time is a coach in Muadz Bin Jabal High School. In its development, it was later discovered that the Muhammadiyah school also assisted in the education process organized by the Salafi-oriented Muadz bin Jabal Islamic Center. This indicates the existence of collaboration and cooperation to nurture each other between religious groups are active in Wakatobi. It also shows moderation in the sense of the willingness of each group to co-exist.

Although the pure Islamic paradigm appears to be explicitly channeled through Muhammadiyah schools to Bajo children, in reality there are more oriented towards local Islamic traditions with traditional trinkets of the past, but until now the transmission flow has not received any opposition or resistance. Until now, there has not been any resistance to the pure Islamic paradigm that was "deliberately" transmitted by young Muhammadiyah activists to Bajo children. There are two possibilities for this. First: Bajo children don't care much about the subject. For them, the most important thing is to get an education or even more pragmatically to get a diploma fulfilled. Besides because they have not been contaminated by provocation of Islam A or B, so that when the paradigm is streamed, there is no problem. Secondly, they come to agree with the conceptualization of pure Islam because the transmitter or agent of pure Islam framed the idea politely, nmely with the positive action approach, an approach that Kuntowijoyo called an approach that emphasizes amar makruf and does not frontally attack tradition (nahi mungkar) (Kuntowidjoyo, 2000).

Based on the description that has been outlined, there seems to be a clear difference between the movements of educational philanthropy carried out by the Muhammadiyah exponents in Wakatobi and various educational philanthropic movements that are much examined by researchers as mentioned in relevant studies. Muhammadiyah's educational philanthropic movement in the Bajo Mola Wakatobi settlement is a move that is struggling over the intention to make 
"liberation", on elements of society that are not only socially marginal economically but also marginally in terms of psycho-social. Therefore, educational philanthropy that is performed by Muhammadiyah in Wakatobi is not only oriented towards efforts to help overcome the financing of education for children who are considered less able, by facilitating funds from philanthropists or CSR funds from financial institutions like many philanthropic institutions do, but deeper into the invisible space that tends to be difficult to overcome with funding. In other words, the area of Muhammadiyah's educational philanthropic movement does not merely revolve around the space of fulfilling educational services from the aspect of funding but it moves far beyond the material dimension.

In addition to aspects of education funding that are not affordable as a result of the reality of the world of educational institutions that are trapped in the network of capitalism, there are still more serious things experienced by Bajo children. Namely the fading of the existential awareness of local children to empower and enlighten their minds with psychological conditions that are entangled in the frame of "sense" of lack of confidence. This condition is strongly suspected to be an effective "trigger" that keeps local children away from the process of social interaction with their relatives who live on land. The next implication is that school-age children in this region are "forced" to ignore or move away from school classrooms and then prefer to go fishing as their traditional livelihood.

In the context of the socio-cultural setting that encompasses Bajo children, the Muhammadiyah exponent as the subject behind the philanthropic movement is well aware of the deterioration of education experienced by local children, the core problem is not merely to overcome the material aspects of an sich. Therefore, the work of Muhammadiyah Wakatobi exponent philanthropy, besides having to break the chain of problems related to financing, Muhammadiyah exponents are required to restore the power or energy of the confidence of sea people's children, to be able to stand upright with the community of land children. To break the chain of acute financing problems because of the high cost of accessing education, Muhammadiyah established a school infrastructure in the middle of the Bajo settlement. The aim was not only to provide affordable educational services in accordance with the economic capacity of the local community, but also to bring learning spaces closer to their environment. In reality, this movement is quite able to provoke local people and children, especially those who are not accommodated in public schools. Another significant evidence to mention the existence of space for appreciation from the local community for the presence of the Muhammadiyah children school is the increasingly large land grants entrusted to Muhammadiyah.

In overcoming the psycho-social problems that approached the local children, as long as the researchers observed and interviewed the teacher (informant), it seemed that no specific action was taken. This reality may be due to the Muhammadiyah exponent, only knowing the problem experienced by local children, they do not have professional resources in the field of counseling. Based on researchers' interviews with local Muhammadiyah exponents, there is a strong impression that to strengthen the interest of schools plus to lift the confidence of local children, one approach taken is to bring schools closer to the local children's environment. As explained earlier, the effort to bring school classrooms closer to Bajo children is based on the mental condition of some local children who lack confidence or lack the ability to socialize with land children. That is why they 
choose to establish a school on the sea. Besides being close to the Bajo environment, this school also mostly accommodates Bajo children, making it possible for them to interact, develop and communicate their ideas more freely without feeling awkward.

The efforts of Surni and the Muhammadiyah community, on the one hand can be appreciated, but it does not mean that these efforts are without problems. Keep in mind, the policy of bringing schools closer with a reason that at the school (they are Bajo children) that they will gather with fellow Bajo people, according to the author is not conducive to foster the multicultural character of Bajo children. Given, their presence in the same room without being interfered with land children will in fact further alienate the social and cultural relations of the Bajo children with land people. On the other hand, it can cause their social progressiveness and sensitivity to be less able to be developed. That is why broader socialization is needed for each child as a process of learning norms, values, roles and all other requirements to enable them to participate effectively in social life. In addition, through socialization, a child can learn to recognize and adapt to his/her environment, in the terms of values, norms, and social structures that exist in the community in that environment. In addition, it can be a tool to preserve, spread, and pass down values, norms, and beliefs that exist in society. That way, these values, norms and beliefs can be maintained by all members of the community.

Empirically, the process of education at the Muhammadiyah School of Sea Children seems to take place naturally and unremarkably. In other words, there is no clear application of special advantages that distinguishes this school from other schools, even in terms of the quality of learning it can be said to be behind the public schools on land. This condition exists due to limited resources and funds in institutional management. In terms of resources, school teachers generally rely on volunteers to greet and distribute their knowledge without clear rewards or even sometimes they have to spend personal funds to reach the school space. While in terms of sources of funding, this school does not yet have a reliable source of funding to improve the quality of learning. However, even their movements are limited by the lack of human resources and funds, the hopes of the Muhammadiyah School of Sea Children's motivation to flare up is like the sun that never tired to light the earth. They hope that through the educational movement that is carried out, local children will at least be able to enjoy education as other children. In addition, through the services of educational institutions that are driven by Muhammadiyah, the motivation of local children can be more elevated so that they can be more confident to enter the cubicles of the study room as a place where they slowly strengthen their self-equity, plus become role models for children around, in term of how cheerful and happy it is to go to school.

Although there is no special counseling conducted to expel local children from lacking self-confidence cubicle, this study found a number of learning activities, both formal and informal, have the potential to shape the vision and insight of local children to be more confident appear in an open space. In the aspect of non-formal learning, local students are given extra-curricular content in the form of Quran recitation and leadership training / Training Center for Muhammadiyah Student Association. Through this program, the students are given leadership material, how to lead a session, ethics to express opinions in the discussion room, appear as protocols, make speeches and a number of games aiming at honing their soft skills. The materials mentioned above basically have the 
potential to increase children's confidence. For example, the courage to appear as an master of ceremony and the courage to express opinions in a discussion room are a number of aspects that in principle can shape a child's confidence. In addition to materials related to organizational skills, local children are also given Al-Islam lessons such as Tawhid, Worship and Akhlaq. The material mentioned last is closely related to the subject matter of Al-Islam and Muhammadiyah terms that they get in the classroom as part of formal learning (Alhamuddin, Alhamuddin, Bukhori, 2016; Alhamuddin, 2017). Through the Muhammadiyah material of local children, besides being equipped with Muhammadiyah's historical knowledge, they are also introduced to a number of Muhammadiyah figures, some of whom are national heroes, including: KH. Ahmad Dahlan, KH. Mas Mansur and Jenderal Sudirman. With this approach, one goal is implied that by understanding the history and struggles of Muhammadiyah figures, it is hoped that students of the Muhammadiyah School of Sea Children can emulate the souls and fighting spirit of the figures. Another aspect found in learning activities in Muhammadiyah School of Sea Children not found in public schools is the Qur'an's tahfidz.

Thus, even though there is no specific therapy carried out by the institution in the form of formal counseling to local children, but in essence efforts which are similar to counseling can be found implicitly in a number of activities, that are applied to local students. A number of the subjects mentioned as well as extracurricular activities appeared to be applied to students of the Muhammadiyah School of Sea Children, according to the author, are naturally productive activities that can be seen as representations to elevate spirit and moral capital, while at the same time forming insight and perspectives which can direct and form the positive character of students.

Referring to the description as described, it can be seen that in overcoming the two problems experienced by Sea People's children, Muhammadiyah's exponents made religion as the basis of their movement. This finding has at least a point of contact with the results of research by Latif et al., which states that the philanthropic movement of Muhammadiyah residents is still dominated by religious views (Latief, 2016). In the context of philanthropic actors, this means thatthe basis of all the movements they plan and build is motivation for religious values. This can be understood, considering that in the basic construct of Muhammadiyah's thinking as stated in its articles of association, it is stated that this organization is an Islamic missionary organization, so it becomes very logical if the motivational building of the organization's efforts in providing educational services cannot be separated from religious missions. In principle, the distribution of religious values through the lessons of Al-Islam and Muhammadiyah terms are in line with the objectives of Islamic education (Alhamuddin, 2018). This is parallel with extra-curricular channel which plays role as a therapy run to lift the enthusiasm of local children. Referring to the facts that researchers found in the field and the results of interviews with a number of informants, it shows that the form of Muhammadiyah's philathropic movement in Waktobi is not just a charity program, but it is closer to the philanthropic social model for social justice (social justice philanthropy). It seems clear that there is something that Muhammadiyah wants to uphold, namely answering public problems by instilling values that are based on religious norms. Efforts to address public problems made by Muhammadiyah Wakatobi exponents are carried out on an ongoing basis. They move in the macro realm, solving problems at the structural level and changing 
systems. This model is expected to be able to bridge or answer the socio-cultural problems that have ensnared local communities so far. Whether it is realized or not, the local Muhammadiyah community has made efforts to mobilize resources to support their activities and to sue structural injustice as a cause of lasting social deterioration experienced by a community, which in this case are children who live in the Bajo environment. In other words, the movement of Muhammadiyah's philanthropy does not only solve the educational problems of Bajo children in the an sich material aspects, but also attempt to answer the root of social problems as previously described.

This research is an illustration of the benefits of philanthropy for the development of social funds, education, economy, and others. Philanthropy provides access to community members who need resources so that they can increase their independence in fulfilling their daily needs. Every philanthropist respects the diversity lives in society: culture, religion and belief, ethnicity, perspective and so on. In addition, it aims to increase the participation of the philanthropic sector by developing the education system in Indonesia thus it can contribute significantly and play an active role in encouraging the impact of educational system development in line with the SDGs.

\section{CONCLUSION}

Bajo children's choice to go to sea instead of going to school is not only caused by economic factors, but also due to psycho-social constraints. That is the inability of Bajo children to interact with mainland children, who may be shaped by olay lesse'e culture. This culture caused a separation between the Bajo and the mainland children and their subsequent development was thought to trigger the inferiority complex within themselves. In this context, the choice of Muhammadiyah to establish an educational institution over the sea in order to bring Bajo children closer to school becomes rational. That is why Muhammadiyah is more interested in establishing schools as a place for seeding human resources. Muhammadiyah believes that through education local children can live happier, more confident and this can empower themselves in a sustainable manner. Muhammadiyah School of Sea Children is managed independently by relying on religious spirit-based beliefs. With that perspective, Muhammadiyah's philatropic activities in the Coral Triangle region are closer to the category of social justice philanthropy. To strengthen the foundation of knowledge gained from the learning space, Bajo children are injected with pure Islamic-based religious values. Even though it is known that the religious patterns of the local community smelled of popular Islamic traditions, the beauty of the transformation of pure Islamic values by the Muhammadiyah community did not experience cultural constraints. This happens because the pure Islamic preaching by community was done with a persuasive approach.

\section{ACKNOWLEDGEMENT}

This article is the result of research conducted in collaboration between the first, second and third authors. the research was conducted in the Bajo community. Thank those who have supported both materially and morally to the Kendari State Islamic Institute of Religion, Universitas Islam Bandung and Imam Bonjol State Islamic University. We also do not forget to thank Muhammadiyah for providing support for research and especially the Bajo marine school community 


\section{AUTHOR CONTRIBUTION STATEMENT}

Muhammad Alifuddin, as the main author of this project. Meanwhile, Alhamuddin as the second and co-author who has professionally provided academic support. Nurjannah was a thrid author in carrying out this research from start to finish. Muhammad Alifuddin as the main researcher was currently working at the State Islamic University of Kendari and as a senior researcher. He collected data and interpreted the data we obtained from the field and studied with educational theories. the second and third authors collected data and analyzed the data findings obtained and outlined in the article.

\section{REFERENCES}

Alhamuddin, Alhamuddin, Bukhori, B. (2016). The Effect of Multiple Intelligence-Based Instruction on Critical Thinking of Full Day Islamic Elementary Schools Students. 21(1), 31-40. https:/ / doi.org/10.19109/td.v21i1.590

Alhamuddin. (2018). Abd Shamad al-Palimbani's Islamic education concept: Analysis of Kitab Hidayah al-Sālikin fi Suluk Māsālāk lil Muttāqin. Qudus International Journal of Islamic Studies, 6(1), 89-102. https:/ / doi.org/10.21043/qijis.v6i1.3717

Alhamuddin, A. (2017). Transdiciplinary: Model Pengembangan Kurikulum Berorientasi Kebutuhan Individu dan Masyarakat. Jurnal Pendidikan Islam Indonesia, 2(1), 55-64. https:/ / doi.org/10.35316/jpii.v2i1.62

Bappenas. (2010). Peran Gerakan Filantropi untuk Keberlanjutan Organisasi Masyarakat Sipi. Google Scholar

Futaqi, S., \& Machali, I. (2018). : Pembiayaan Pendidikan Berbasis Filantropi Islam: Strategi Rumah Pintar BAZNAS Piyungan Yogyakarta. Manageria, 3(3). https:// doi.org/10.14421/manageria.2018.32-02

Gay, L. R. \& P. A. (2000). Educational Research, Compencies for Analysis and Aplication, sixth edition. America: Prentice Hall. Google Scholar

Helmut K. Anheier. (2006). Creative Philanthropy: Toward a New Philanthropy for the Twenty-First Century 1st Edition (Diana Leat). London: Routledge. Google Scholar

Kuntowidjoyo. (2000). Pengantar Jalan Baru Muhammadiyah. Yogyakarta: Bentang.

Latief, H. (2016). Prilaku dan Potensi Filantropi Warga Muhammadiyah (Survey di 11 Kota Besar Indonesia. Yogyakarta: Lembaga Penelitian, Publikasi dan Pengembangan Pendidikan UMY. Google Scholar

Latif, H. (2010). Melayani Umat: Filatropi Islam dan Ideologi Kesejahteraan Kaum Modernis. Jakarta: Gramedia. Google Scholar

Madlan, L. B. (2014). The Prejudice of Bajau: From Own and Others Ethnic Perspective:A Preliminary Study in Sabah,. International Journal of Information and Education Technology, 4(2). Google Scholar

Miles, M. B., Huberman, A. M., \& Saldaña, J. (2018). Qualitative data analysis: A methods sourcebook. Sage publications. Google Scholar

Moustakas, C. (1994). Phenomenologi Research Methode. London: Sage Publication.

Nasruddin. (2004). Bajo dan bukan bajo Studi Tentang Perubahan Makna Sama dan Bagai pada Masyarakat Bajo di Desa Sulaho Kecamatan Lasusua Kabupaten Kolaka Sulawesi Tenggar Lasusua Kabupaten Kolaka Utara (Universitas airlangga).Google Scholar

Nasrullah, A. (2015). Pengelolaan Dana Filantropi untuk Pemberdayaan Pendidikan Anak Dhuafa (Studi Kasus pada BMH Cabang Malang Jawa Timur). Hunafa Jurnal Studi Islamika, 12(1). https:/ / doi.org/10.24239/jsi.v12i1.377.1-18

Putra, H. S. A. (1995). Analisis Struktural dan Makna Mitos Orang Bajo. Yogyakarta.

Shofa, R. A., \& Machali, I. (2017). Filantropi Islam Untuk Pendidikan: Strategi 
School of Anak Laut (Sea Children): Educational Philanthropy Movement in The Bajo Community of The Three-Coral World Center

Pendanaan Dompet Dhuafa dalam Program Sekolah Guru Indonesia (SGI). Madaniah, 21(1). http:/ / dx.doi.org/10.29300/madania.v21i1.242

Subando, J. (2016). Pengelolaan Sekolah Berbasis Filantropi (Studi Kasus di SMK Gratis Smart Informatika Surakarta). Wahana Akademika, 3(1). Google Scholar

Subki, R. (2019). Tri Sakti Muhammadiyah, Jangan Gagap Melihat Zaman. Kompas. Retrieved from Kompas.Com

Suryanegara, E. (2015). Social Change on Bajo Tribe: Case Study in Wakatobi South East of Sualwesi. 17(1), 75. Google Scholar

Sutrisno, M. ., \& Putranto, H. (2005). Teori-Teori Kebudayaan. Yogyakarta: Kanisius.

\section{Copyright Holder :}

(C) Alifudin, M., Alhamuddin, A., \& Nurjannah, N.. (2021).

First Publication Right :

(C) Jurnal Iqra' : Kajian Ilmu Pendidikan

This article is under:

(1) (1) (2) 